\title{
Antibacterial, antioxidant and cytotoxic activities of different fractions of acetone extract from flowers of Dipterocarpus intricatus Dyer (Dipterocarpaceae)
}

\author{
Hong Thia Le ${ }^{1}$, Thao Nguyen Luu², Huynh Mai Thu Nguyen², Dang Hoai Trang Nguyen², Pham Tan \\ Quoc Le ${ }^{2}$, Ngoc Nam Trinh 3 , Van Son Le ${ }^{4}$, Hoang Dung Nguyen ${ }^{5} \&$ Hong Thien Van ${ }^{2 *}$ \\ ${ }^{1}$ Institute of Environmental Science, Engineering and Management, Industrial University of Ho Chi Minh City, No. 12 Nguyen Van Bao Street, \\ Go Vap District, Ho Chi Minh City, Vietnam \\ ${ }^{2}$ Institute of Biotechnology and Food Technology, Industrial University of Ho Chi Minh City, No. 12 Nguyen Van Bao Street, Go Vap District, Ho \\ Chi Minh City, Vietnam \\ ${ }^{3}$ Office of Science Management and International Affairs, Industrial University of Ho Chi Minh City, No. 12 Nguyen Van Bao Street, Go Vap \\ District, Ho Chi Minh City, Vietnam \\ ${ }^{4}$ Binh Chau-Phuoc Buu Nature Reserve, Bung Rieng Ward, Xuyen Moc District, Ba Ria-Vung Tau Province, Vietnam \\ ${ }^{5}$ Institute of Tropical Biology, Vietnam Academy of Science and Technology, No. 9/621 Ha Noi Highway, Linh Trung Ward, Thu Duc District, Ho \\ Chi Minh City, Vietnam \\ *Email: vanhongthien@iuh.edu.vn
}

\section{ARTICLE HISTORY}

Received: 05 January 2021

Accepted: 21 February 2021

Published: 01 April 2021

\section{KEYWORDS}

Dipterocarpus intricatus

Antibacterial activity

Antioxidant activity

Cytotoxic activity
ABSTRACT

This study has shown for the first time the antimicrobial, antioxidant and cytotoxicity of 3 fractions of acetone extract, including hexane, chloroform and ethyl acetate from flowers of Dipterocarpus intricatus. Antibacterial test using disc diffusion method showed that the chloroform and ethyl acetate fractions inhibited the growth of all the tested bacteria, including Escherichia coli, Pseudomonas aeruginosa, Salmonella enteritidis, Salmonella typhimurium, Bacillus cereus and Staphylococcus aureus while the hexane fraction showed the antibacterial activity against B. cereus and S. enteritidis. Antioxidant activity and cancer cell resistance of those extracts were conducted using DPPH and MTT methods respectively. As a result, the DPPH radical scavenging activity of the hexane, chloroform and ethyl acetate fractions were determined with the $\mathrm{IC}_{50}$ values of $0.508,0.22$ and $0.075 \mathrm{mg} / \mathrm{mL}$ respectively while the cytotoxicity to HepG 2 cell line of those fractions was $163.3 \mathrm{ppm}, 106.7 \mathrm{ppm}$ and $459.3 \mathrm{ppm}$. These results suggested the potential application of these fractions isolated from $D$. intricatus flowers as the natural antimicrobial, antioxidant and cytotoxic agents for medicine.

\section{Introduction}

In Dipterocarpaceae, Dipterocarpus has been known as the third largest genus with 75 species distributed in tropical regions of Asia, particularly in Southeast Asia, such as Cambodia, Indonesia, Malaysia, Myanmar, Thailand and Vietnam (1). Being home to 12 Dipterocarpus species, Vietnam is now considered as the biodiversity hotspot for the Dipterocarpaceae (2). Many species of this genus have been well known for their uses as folk medicine. For example, D. alatus and $D$. dryobalanops have been used for the treatment of rheumatism, dysmenorrhea (3-4). In addition, some other species, including $D$. gracilis, $D$. turbinatus, $D$. turbinatus and D. tuberculatus are also used to treat gonorrhoea, urinary gleets, ulcer, ringworm and skin diseases (5). Some studied have recorded the presence of several groups of active compounds, including sesquiterpenes, triterpenes and coumarin derivatives as well as their bioactivities isolated using different solvents $(3,5)$.

Dipterocarpus intricatus Dyer is a deciduous species, 15 - 25 meters tall, whose habitat is dry deciduous dipterocarp forest. In Vietnam, it has been widely used as the folk medical treatments for several diseases, such as gonorrhea, rheumatism and skin diseases. Nowadays, $D$. intricatus is considered as a rare species (6) and therefore, the number of studies

(C) Le et al (2021). This is an open-access article distributed under the terms of the Creative Commons Attribution License, which permits unrestricted use, distribution and reproduction in any medium, provided the original author and source are credited (https://creativecommons.org/licenses/by/4.0/).

To cite this article: Le H T, Luu T N, Nguyen H M T, Nguyen D H T, Le P T Q, Trinh N N, Le V S, Nguyen H D, Van H T. Antibacterial, antioxidant and cytotoxic activities of different fractions of acetone extract from flowers of Dipterocarpus intricatus Dyer (Dipterocarpaceae). Plant Science Today. 2021;8(2):273-277. https://doi.org/10.14719/pst.2021.8.2.1086 
on this species is limited and its bioactivity is still unknown in Vietnam, D. intricatus is distributed from Kon Tum Province to Phu Quoc island, Kien Giang Province (2). There has been only one study (7) reporting the chemical composition of this species so far. In the study, eight phenolic constituents, including (Z)- $\varepsilon$-viniferin, (-)-4'-Omethylepigallocatechin 3-gallate, 11-Ogalloylbergenin, bergenin, 4-hydroxybenzaldehyde, vanillin, vanillic acid and syringic acid were found in the ethanolic extract of $D$. intricatus stems.

Therefore, the study on chemical profiles and bioactivity of other extracts of $D$. intricatus, should be conducted to further apply it in medical uses further. In this study, the antibacterial, antioxidant and cytotoxic activities of 3 fractions (hexane, chloroform and ethyl acetate) of acetone extract from $D$. intricatus flowers were investigated for the first time.

\section{Materials and Methods}

\section{Plant materials}

The sampling of $D$. intricatus was conducted in Binh Chau-Phuoc Buu Nature Reserve, Bung Rieng ward, Xuyen Moc District, Ba Ria-Vung Tau Province, Vietnam, $\left(10^{\circ} 31^{\prime} 11^{\prime \prime N}\right.$; $107^{\circ} 31^{\prime} 18^{\prime \prime E}$, May 10, 2020) (Fig. 1). The voucher specimens VS Le 401 and 402 were deposited at the Herbarium of Binh Chau-Phuoc Buu Nature Reserve.

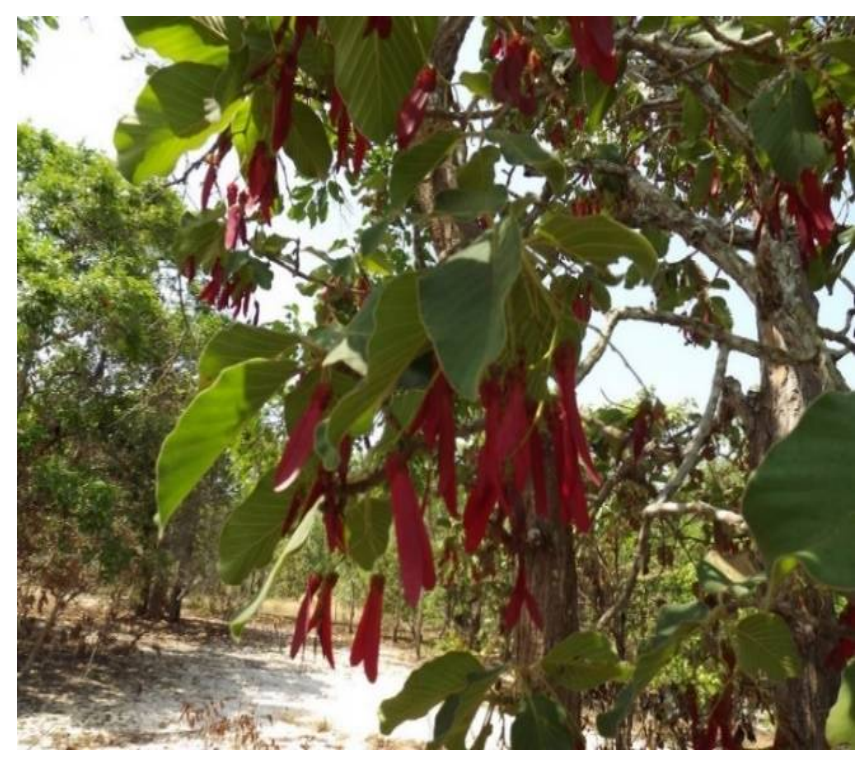

Fig. 1. Dipterocarpus intricatus Dyer in Habitat with mature flowers.

\section{Bacterial strains}

The bacterial strains used to study the antibacterial activity of the acetone extract from the flowers of D. intricatus included Escherichia coli (ATCC 25922), Pseudomonas aeruginosa (ATCC 27853), Salmonella enteritidis (ATCC 13976), Salmonella typhimurium (ATCC 13311)) and two Gram-positive bacteria (Bacillus cereus (ATCC 11774), Staphylococcus aureus (ATCC 25923), which were preserved in $20 \%$ glycerol solution at $20{ }^{\circ} \mathrm{C}$ and cultivated in Luria-Bertani broth at $37^{\circ} \mathrm{C}$ for $24 \mathrm{hr}$ to activate before the assay.

\section{Extraction procedures}

Sliced specimens were modestly dried at $50{ }^{\circ} \mathrm{C}$ until constant weight and ground into powder. The maceration of $100 \mathrm{gm}$ of the dried powders in $500 \mathrm{ml}$ of acetone $99 \%$ solution was conducted at room temperature for $72 \mathrm{hrs}$. A Whatman paper was used to filter the extract. The process was repeated twice. The total filtrate was concentrated on a rotary evaporator under the reduced pressure at $60{ }^{\circ} \mathrm{C}$ until brown extract was obtained. The brown extract was then dried to completely remove the remaining acetone (8). About 3 gms of the brown extract was dissolved in $30 \mathrm{ml}$ of distilled water. The resulting suspension was then mixed with $30 \mathrm{ml}$ n-hexane, shaken and left standing for layer formation. The upper layer (n-hexane) was collected. The process was repeated thrice to obtain $90 \mathrm{ml}$ hexane extract which was then concentrated on a rotary evaporator at $40{ }^{\circ} \mathrm{C}$ to obtain the hexane fraction. The lower layer was collected and used to subsequently collect chloroform extract and ethyl acetate fractions using the above process which was applied to obtain the nhexane fraction.

\section{Antibacterial activity assay}

Disc diffusion test was the method to investigate the antibacterial activity according to the CLSI guideline (9). The bacterial strains were cultivated in LuriaBertani Broth until the value of 0.5 McFarland was reached. $100 \mu \mathrm{l}$ aliquot of the bacterial culture was spread on Mueller Hinton agar plate before the sterile paper discs containing $10 \mu \mathrm{l}$ of the studied extract solution were placed on the plate surface. The plate incubation was then maintained at $37{ }^{\circ} \mathrm{C}$ for 16 $18 \mathrm{hrs}$ before measuring the zone of inhibition. The diameter of zone inhibition was used to evaluate the resistance of studied extract to the bacterial strains.

\section{Determination of antioxidant activity of extract}

The method described (10) with minor modifications was used to study the DPPH radical scavenging activity of the extract. $100 \mu \mathrm{l}$ of DPPH solution (300 $\mu \mathrm{m})$ was mixed with $100 \mu \mathrm{l}$ of sample and placed in dark $30 \mathrm{~min}$ at $37{ }^{\circ} \mathrm{C}$ prior to the optical density measurement at $517 \mathrm{~nm}$. The DPPH radical scavenging activity $\left(\mathrm{DPPH}_{\mathrm{RSA}}\right)$ of the extract was calculated using the following formula:

$$
\mathrm{DPPH}_{\mathrm{RSA}}(\%)=\left(\mathrm{Abs}_{\text {control }}-\mathrm{Abs}_{\text {sample }}\right) / \mathrm{Abs}_{\text {control }} \times 100 \%
$$

where $\mathrm{Abs}_{\text {control }}$ stands for the absorbance of the $\mathrm{DPPH}$ radical in methanol and $\mathrm{Abs}_{\text {sample }}$ stands for the absorbance of the DPPH radical solution mixed with the sample extract. The $\mathrm{IC}_{50}$ value (the concentration of the sample that can scavenge $50 \%$ of DPPH free radical) was estimated from the antioxidant activity curve obtained at various concentration extracts.

\section{Cytotoxicity assay}

The cytotoxicity of the tested samples to hepatoma (Hep-G2) cell line was performed using MTT method (11), in which 96 well - plate format was used. The tested compounds were dissolved in DMSO and then stepwise diluted to the final concentration of $0-200$ $\mu \mathrm{g} / \mathrm{ml}$ after $24 \mathrm{hr}$ of incubation. The positive control used was Cisplatin. The experiment with three biological replicates was performed to obtain the $\mathrm{IC}_{50}$ 
values (concentration of the compound which have $50 \%$ inhibition on the cell growth). These $\mathrm{IC}_{50}$ values were also determined from cytotoxic activity curve obtained at various concentration extracts.

\section{Data analysis}

All experiments were performed in triplicate and the results were expressed in the form of a mean \pm standard deviation (SD). The data obtained were analyzed by the one-way analysis of variance (ANOVA) method which was used to compare different groups using Fisher's least significant difference (LSD) procedure $(\mathrm{p}<0.05)$. Statistical analysis was performed using Statgraphics Centurion XV (version 15.1.02, Statgraphics Technologies, Inc., USA).

\section{Results and Discussion}

\section{Antibacterial activity}

The results of antibacterial activity from the hexane, chloroform and ethyl acetate fractions of acetone extract from the $D$. intricatus flowers were presented in Fig. 2 and Table 1. Chloroform and ethyl acetate fractions were proved to be able to inhibit the growth

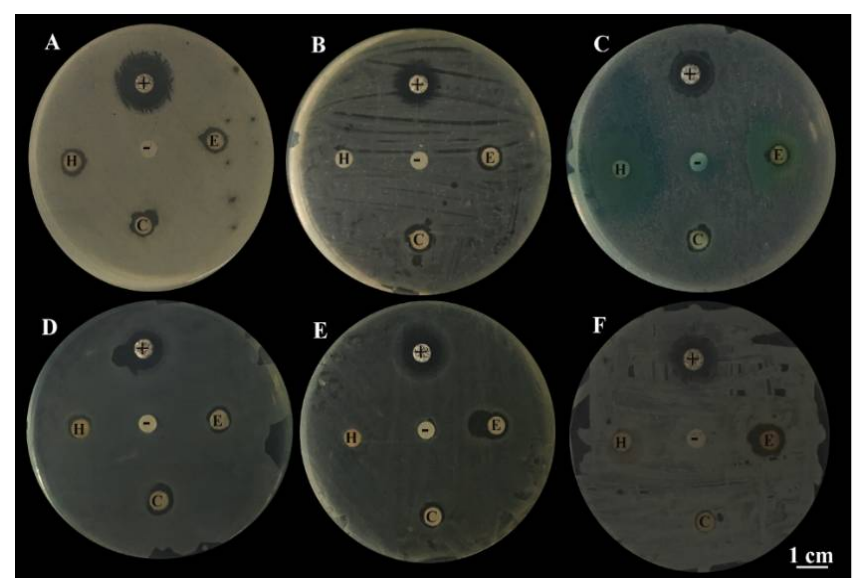

Fig. 2. Antibacterial activity of hexane (H), chloroform (C) and ethyl acetate $(E)$ fractions from $D$. intricatus flowers against 6 bacterial strains. A. B. cereus, B. E. coli, C. P. aeruginosa, D. S. enteritidis, E. S. typhimurium, F. S. aureus. (-) Negative control with sterilized distilled water, (+) Positive control with discs containing gentamicin. active against $B$. cereus $(9.2 \pm 0.3 \mathrm{~mm})$ and $S$. enteritidis $(7.3 \pm 0.6 \mathrm{~mm})$.

Many recent studies have recorded the antibacterial ability of various extracts from different parts of species in the genus Dipterocarpus. For example, the extracts of the stem and bark of $D$. verrucosus inhibited the growth of many strains of bacteria, such as Pseudomonas aeruginosa, Klebsiella pneunomonia, Salmonella paratyphi, Bacillus subtilis, Staphylococcus aureus and E. coli (12-17). Reports are on the antibacterial ability of methanol extracts from the bark of $D$. alatus to Staphylococcus aureus with Minimum Inhibitory Concentration (MIC) of $500 \mu \mathrm{g} /$ $\mathrm{ml}$ and Minimum Bactericidal Concentration (MBC) of $1000 \mu \mathrm{g} / \mathrm{ml}$, twig extract with Minimum Inhibitory Concentration (MIC) of $250 \mu \mathrm{g} / \mathrm{ml}$ and Minimum Bactericidal Concentration (MBC) $500 \mu \mathrm{g} / \mathrm{ml}$ and leaf extract with $500 \mu \mathrm{g} / \mathrm{ml}$ for both values (18). Recently, it was also showed that various extracts such as petroleum ether, chloroform and ethyl acetate extract from $D$. turbinatus displayed stronger inhibition of certain gram-negative and gram-positive bacteria, such as $P$. aeruginosa, $S$. aureus, $E$. coli and E. faecalis (19).

\section{Antioxidant and cytotoxic activities activity}

Fig. 3 shows that $\mathrm{IC}_{50}$ of the hexane, choloroform and ethyl acetate fractions reached $0.508,0.22$ and 0.075 $\mathrm{mg} / \mathrm{ml}$, respectively. Results showed that ethyl acetate extract had the highest antioxidant activity compared to the other two fractions. Many recent studies have shown the percent DPPH inhibition of the extracts from Dipterocarpus species. For example, it was showed that the $\mathrm{IC}_{50}$ value of the methanol extracts from the leaves, twigs and bark of $D$. alatus were $26.76 \mu \mathrm{g} / \mathrm{mL}, 16.53 \mu \mathrm{g} / \mathrm{ml}$ and $5.76 \mu \mathrm{g} / \mathrm{ml}$, respectively (20). Additionally, it was demonstrated that the $\mathrm{IC}_{50}$ value of the methanol extracts from the bark of $D$. verrucosus and D. cornutus were $80 \mu \mathrm{g} / \mathrm{ml}$ and $210 \mu \mathrm{g} /$ $\mathrm{ml}(21)$.

The strong antioxidant capacity of the extracts was not equivalent to the cytotoxicity activity in this study. For example, the antioxidant capacity of hexane fraction was weaker than that of ethyl acetate, but its cytotoxicity was stronger (Fig. 4). The results showed that the highest cytotoxicity was

Table 1. Inhibition zone of hexane, chloroform and ethyl acetate fractions isolated from the aerial parts $D$. intricatus flowers against six bacterial strains

\begin{tabular}{lccc}
\hline \multirow{2}{*}{ Tested bacteria } & \multicolumn{2}{c}{ Growth inhibition zone (mm) } \\
\cline { 2 - 4 } & Hexane & Chloroform & Ethyl acetate \\
\hline Bacillus cereus & $9.2 \pm 0.3^{\mathrm{Ba}}$ & $9.3 \pm 0.6^{\mathrm{Ca}}$ & $9.5 \pm 0.5^{\mathrm{BCa}}$ \\
\hline Escherichia coli & - & $11.2 \pm 1.0^{\mathrm{Da}}$ & $10.7 \pm 0.6^{\mathrm{Da}}$ \\
\hline Pseudomonas aeruginosa & - & $8.3 \pm 0.3^{\mathrm{BCb}}$ & $7.3 \pm 0.6^{\mathrm{Aa}}$ \\
\hline Salmonella enteritidis & $7.3 \pm 0.6^{\mathrm{Aa}}$ & $10.8 \pm 0.8^{\mathrm{Dc}}$ & $8.8 \pm 0.8^{\mathrm{Bb}}$ \\
\hline Salmonella typhimurium & - & $8.2 \pm 0.3^{\mathrm{ABa}}$ & $15.3 \pm 0.6^{\mathrm{Bb}}$ \\
\hline Staphylococcus aureus & - & $7.2 \pm 0.3^{\mathrm{Aa}}$ & $15.2 \pm 0.3^{\mathrm{Bc}}$ \\
\hline
\end{tabular}

of all of the six studied bacteria with the corresponding inhibition diameter mentioned in the brackets: $B$. cereus $(9.3 \pm 0.6 \mathrm{~mm}$ and $9.5 \pm 0.5 \mathrm{~mm}), E$. coli $(11.2 \pm 1.0 \mathrm{~mm}$ and $10.7 \pm 0.6 \mathrm{~mm}), P$. aeruginosa $(8.3 \pm 0.3 \mathrm{~mm}$ and $7.3 \pm 0.6 \mathrm{~mm}), S$. enteritidis $(10.8 \pm 0.8$ $\mathrm{mm}$ and $8.8 \pm 0.8 \mathrm{~mm}), S$. typhimurium $(8.2 \pm 0.3 \mathrm{~mm}$ and $10.3 \pm 0.3 \mathrm{~mm})$ and $S$. aureus $(7.2 \pm 0.3 \mathrm{~mm}$ and $12.5 \pm 0.5 \mathrm{~mm}$ ) while the hexane fraction was only found in chloroform fraction ( $\mathrm{IC}_{50}$ of $106.7 \mathrm{ppm}$ ), followed by hexane fraction $\left(\mathrm{IC}_{50}\right.$ of $163.3 \mathrm{ppm}$ ) and ethyl acetate fraction ( $\mathrm{IC}_{50}$ of $459.3 \mathrm{ppm}$ ).

Many recent studies on the extracts from the species of genus Dipterocarpus have shown their resistance to many cancer cell lines. For example, it was showed that the methanol extracts from the 
leaf, bark and twig of $D$. alatus had cytotoxic effects on 5 cell lines, including HCT116, SKLU1, SKMEL2, SiHa and U937, in which, 3 types of extracts
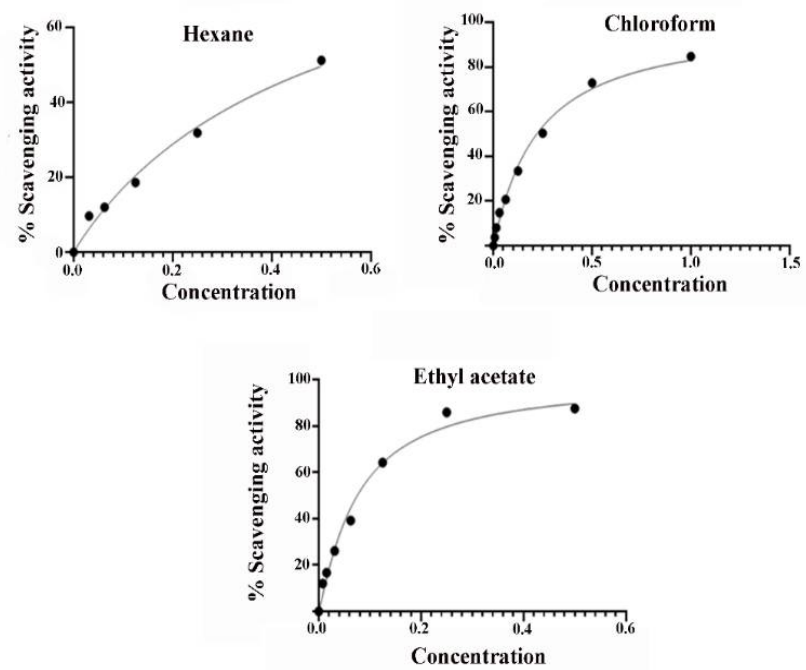

Fig. 3. Radical scavenging activity of hexane, chloroform and ethyl acetate fractions from $D$. intricatus flowers.
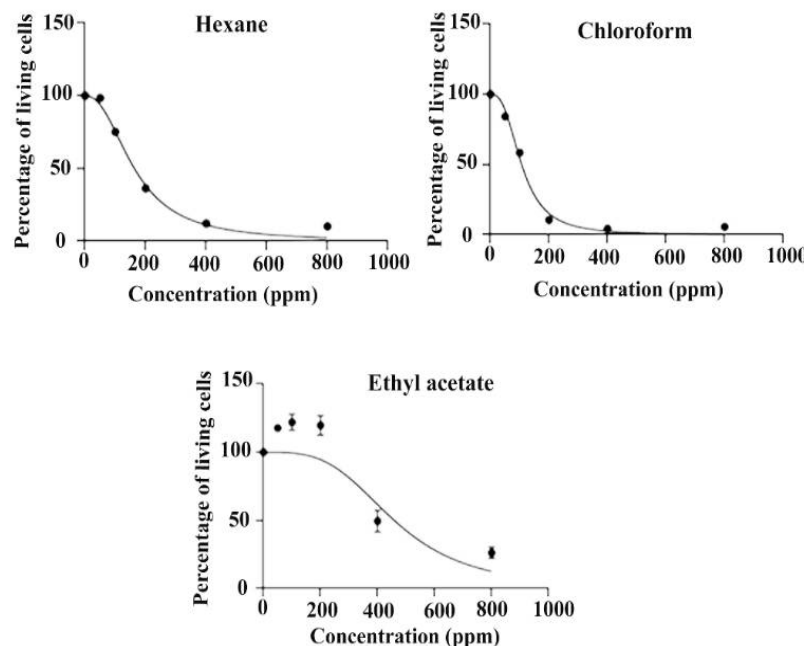

Fig. 4. Cytotoxic activity of hexane, chloroform and ethyl acetate fractions from $D$. intricatus flowers against hepatoma (Hep-G2).

from the leaf, bark and twig of $D$. alatus were most active against U937 cell lines with $\mathrm{IC}_{50}$ of $91.3 \mu \mathrm{g} /$ $\mathrm{ml}, 106.2 \mu \mathrm{g} / \mathrm{ml}$ and $128.9 \mu \mathrm{g} / \mathrm{ml}$, respectively (20). Similarly, in a recent study, the leaves, bark and twig extracts of $D$. alatus were also shown to be effective against several cancer cell lines, such as Vero, HepG2, HeLa and Jurkat (22). In addition, many chemical compounds from Dipterocarpus have also been shown to inhibit many cancer cell lines. For example, 6 compounds including Diptoindonesin E, (-) - $\varepsilon$-Viniferin, (-) - a-Viniferin, Vaticanol B and (-) - Hopeaphenol extracted from D. hasseltii were investigated against murine leukemia P-388 cell lines with IC50 of $73.8 \mu \mathrm{M}, 18.1$ $\mu \mathrm{M}, 25.7 \mu \mathrm{M}, 46.4 \mu \mathrm{M}$ and $5.2 \mathrm{M}$ respectively (13). Five new compounds of triterpene groups were extracted from the stem of $D$. obtusifolius, of which 2 compounds (27-demethyl-20 (S) -dammar-23-ene20-ol-3, 25-dione and 3-epi-Cecropic Acid) were active against to 5 cancer cell lines, including HepG2, SK-OV-3, A-549, MCF-7 and SNU-1 (23).

\section{Conclusion}

The study showed that the antibacterial ability of chloroform and ethyl acetate fractions were effective against six strains of bacteria, including $B$. cereus, $E$. coli, $P$. aeruginosa, $S$. enteritidis, $S$. typhimurium and $S$. aureus while hexane fraction showed remarkable antimicrobial activity against $B$. cereus and $S$. enteritidis strains. In addition, hexane, chloroform and ethyl acetate fractions had an antioxidant activity on DPPH radical as well as a cytotoxic effect on HepG2 cell lines. Based on the results in this study, fractions isolated from $D$. intricatus flowers could be potentially used as natural antimicrobial, antioxidant and cytotoxic agents for medicine.

\section{Authors' contributions}

Hong Thien Van and Hong Thia Le designed this study. The samples were collected by Van Son Le, a staff of Binh Chau-Phuoc Buu Nature Reserve. All authors performed experiments and handled the research data. Data analysis was conducted by Hong Thien Van and Hong Thia Le. Hong Thien Van drafted the manuscript and resolved all the queries of reviewers.

\section{Conflict of interests}

No conflict of interest was declared by the authors.

\section{References}

1. Ashton P. Dipterocarpus baudii, The IUCN red list of threatened species. Available from: www. iucnredlist. Org, 2014.

2. Pham HH, Cây cỏ Việt Nam: An Illustrated Flora of Vietnam. Youth Publishing House, Ho Chi Minh City, Vietnam, 2000.

3. Wibowo A, Ahmat N, Hamzah AS, Ismail NH, Ahmad R, Jaafar FM. Resveratrol oligomers from the stem bark of Dryobalanops aromatica. Biochemical Systematics and Ecology. 2012;40:62 64. https://doi.org/10.1016/j.bse.2011.09.013

4. Pauline DYP. Plants used in Cambodia. Self-published, printed by Imprimerie Olympic, Phnom Penh, 2000.

5. Aslam MS, Ahmad MS, Mamat AS. A phytochemical, ethnomedicinal and pharmacological review of genus Dipterocarpus. International Journal of Pharmacy and Pharmaceutical Sciences. 2015;7(4):27-38.

6. Appanah S, Turnbull JM. A Review of Dipterocarpus: Taxonomy, ecology and silviculture. Center for International Forestry Research, Bogor, 1998.

7. Seo C, Ahn EK, Lee JA, Kang JS, Byun HW, Hong SS. Phenolic contituents of the stems of Dipterocarpus intricatus. Chemistry of Natural Compounds. 2020;56:920-22. https://doi.org/10.1007/ s10600-020-03187-9

8. Bobinaite $\mathrm{R}$, Viskelis $\mathrm{P}$, Sarkinas A, Venskutonis PR Phytochemical composition, antioxidant and antimicrobial properties of raspberry fruit, pulp, and marc extract. Journal of Food.2013;11:334-42.

https://doi.org/10.1080/19476337.2013.766265

9. Clinical and Laboratory Standards Institute. Methods for Antimicrobial Dilution and Disk Susceptibility of Infrequently Isolated or Fastidious Bacteria, Approved Guideline, 2nd. ed CLSI document M45-A2. Clinical and Laboratory Standards Institute, 950 West Valley Roadn Suite 2500,Wayne, Pennsylvania 19087, USA, 2010.

10. Thaipong K, Boonprakob U, Crosby K, Cisneros ZL, Hawkins BD. Comparison of ABTS, DPPH, FRAP, and ORAC assays for 
estimating antioxidant activity from guava fruit extracts. Journal of Food Composition and Analysis. 2006;19:669-75. https://doi.org/10.1016/j.jfca.2006.01.003

11. Hussain RF, Nouri AME, Oliver RTD. A new approach for measurement of cytotoxicity using colorimetric assay. Journal of Immunological Methods. 1993;160(1):89-96. https://doi.org/10.1016/0022-1759(93)90012-v

12. Gupta AS, Dev S. Studies in sesquiterpenes-XLVI: Sesquiterpenes from the oleoresin of Dipterocarpus pilosus: Humulene epoxide-III, caryophyllenol-I and caryophyllenol-II. Tetrahedron. 1971;27(3):635-44. https://doi.org/10.1016/S00404020(01)90731-8

13. Khiev P, Kwon OK, Song HH, Oh SR, Ahn KS, Lee HK. Cytotoxic terpenes from the stems of Dipterocarpus obtusifolius collected in Cambodia. Biological and Pharmaceutical Bulletin. 2012;60(8):955-61. https://doi.org/10.1248/cpb.c12-00012

14. Barry AL, Coyle MB. Methods of measuring zones of inhibition with the Bauer-Kirby disk susceptibility test. Journal of Clinical Microbiology. 1979;10:8858-99.

15. Blois MS. Antioxidant determinations by the use of a stable free radical. Nature. 1958;181:1199-1200.

16. Velioglu YS, Mazza G, Gao L, Oomah BD. Antioxidant activity and total phenolics in selected fruits, vegetables, and grain products. Journal of Agricultural and Food Chemistry. 1998;46:4113-4117. https://doi.org/10.1021/jf9801973

17. Osawa T, Namiki M. A novel type of antioxidant isolated from leaf wax of Eucalyptus leaves. Agricultural and Biological Chemistry. 1981;45(3):735-39. https://doi.org/10.1080/00021369.1981.10864583

18. Chatuphonprasert W, Tatiya-aphiradee N, Thammawat S, Yongram C, Puthongking P, Jarukamjorn K. Antibacterial and wound healing activity of Dipterocarpus alatus Crude extract against methicillin-resistant Staphylococcus aureus-induced superficial skin infection in mice. Journal of Skin and Stem Cell. 6(1);e99579. https://doi.org/10.5812/jssc.99579.

19. Biswas D, Mahalakshmi B, Samelu B, Devadas M, Suresehkumar SV. Antimicrobial activity of ethanol extracts and isolated fractions Shorea robusta Gaertn f and Dipterocarpus turbinatus Gaertn f. Pharmacognosy $\begin{array}{ll}\text { Communications. 2020;10(2):102-07. https://doi.org/ } & \text { 20 }\end{array}$ 10.5530/pc.2020.2.19

20. Yongram C, Sungthong B, Puthongking P, Weerapreeyakul N. Chemical composition, antioxidant and cytotoxicity activities of leaves, bark, twigs and oleo-resin of Dipterocarpus alatus Molecules. 2019;24(27):3083. https://doi.org/10.3390/molecules24173083

21. Zain WZWM, Ahmat N, Osman CP. Antioxidant activities of oligostilbenoids from the stem bark of Dipterocarpus verrucosus, Dipterocarpus crinitus and Dipterocarpus cornutus. International Journal of Engineering \& Technology. 2018;7(4): 409-14. http://dx.doi.org/10.14419/ijet.v7i4.18.21979

22. Yongram C, Tadtong S, Weerapreeyakul N, Puthongking P. The preliminary study of Yang Na (Dipterocarpus alatus Roxb. ex G.Don) extracts on anticancer and antifungal activities and the HPLC analysis of the phenolic compounds. Journal of Thai Traditional and Alternative Medicine. 2019;17(3):437-46.

23. Muhtadi, Euis H. Hakim, Juliawaty Ld, Syah YM, Achmad SA, Latip J, Ghisalberti EL. Cytotoxic resveratrol oligomers from the tree bark of Dipterocarpus hasseltii. Fitoterapia. 2006;77(78)550-55. https://doi.org/0.1016/j.fitote.2006.07.004 